\title{
THE USE OF VIDEO STREAMING LEARNING MEDIA IN GEOGRAPHIC LEARNING OUTCOMES BY NOTING LEARNING MOTIVATION
}

\author{
Resita Ramadhani ${ }^{1}$, Pranichayudha Rohsulina ${ }^{2}$, Muh. Husyain Rifa'i ${ }^{3}$ \\ 1,2,3 Departement of Educational Technology, Universitas Veteran Bangun Nusantara \\ Email: geografiunivet@gmail.com
}

\begin{abstract}
The purpose of this study is to find out how to use streaming-based audio visual video media on the learning outcomes of geography subjects on the subject of hydrosphere dynamics by paying attention to students' learning motivation. The type of research used is experiment. The study was conducted on April 162018 until May 16 2018. In this study data was collected through several techniques, namely by using documentation methods, test methods, and questionnaires. The results of this study concluded that there were no differences in geography learning outcomes that applied streaming-based video audio visual media and did not use audio visual media. There is no difference in learning motivation that applies audio visual video, and there is a relationship between the use of audio visual media and learning outcomes on student learning motivation.
\end{abstract}

Keywords: Audio Visual Video, Learning Outcomes, Learning Motivation.

\section{A. INTRODUCTION}

Education is an aspect of life that is very basic for the development of nation's country. Education is very significant for us to consider in this era that is advancing the development of its current technology. Quality education will produce quality human resources that can support national development. The education process will often be encountered in one place, it is school where there is a learning process.

In carrying out learning, the teacher consciously plans activities systematically and is guided by a set of rules and plans about education that are packaged in the form of a curriculum. Continuous curriculum is refined to improve the quality of education and oriented towards the progress of the national education system, but in reality, it cannot be 
maximally realized. One of the problems faced in the world of education in Indonesia is the weak learning process.

Based on the observations, this school learning process does not improve students' creativity. Teachers at this school carry out teaching and learning activities using conventional methods or lectures so that the learning atmosphere seems rigid and dominated by teacher. When it is viewed from students learning outcomes, it turns out the results that are still not satisfactory, the learning outcomes are below the Minimum Completion Criteria Standard (Standar Kriteria Ketuntasan Minimal/KKM).

To overcome this problem there needs to be appropriate learning media. It is also necessary to provide flexibility in the interaction of educators with students during teaching and learning process. Interaction can have a positive impact by giving motivation and mutuality to students to follow the learning process. The use of media in Geography learning is very necessary. Viewed from the discussion of various material in geographic subjects which is quite a lot.

By this background, this author intends to conduct a study entitled "The use of streaming based on audio visual video learning media on the learning outcomes of geography subjects on the subject of hydrosphere dynamics by paying attention to the learning motivation of IPS' students grade X at Weru High School 2018.

\section{B. RESEARCH METHODS}

This research was conducted on X IPS grade students of Senior High School 1 Weru. The focus of the study is 1) Is there an audiovisual influence on student learning outcomes 2) Is there an audiovisual influence on learning motivation 3 ) Is there a relationship between audiovisual and learning outcomes and student motivation, the implementation of experiments is carried out taking into account the level of student abilities 
and learning activities which include teacher-student interactions, student interaction with elements involved in learning activities.

The technique used in analyzing data is to determine the test instrument using the following formula:

\section{Validity}

According to Sugiharto and Sitinjak (2006) validity is related to a change that measures what should be measured.

$$
\mathrm{r}_{\mathrm{xy}}=\frac{N \sum X Y-\left(\sum X\right)\left(\sum Y\right)}{\sqrt{\left\{N \sum X^{2}-\left(\sum X\right)^{2}\right\}\left\{N \sum Y^{2}-\left(\sum Y\right)^{2}\right\}}}
$$

(Arikunto, $2008: 72$ )

Information:

$\mathrm{r}_{\mathrm{xy}}=$ Correlation Coefficient between $\mathrm{X}$ symptom and $\mathrm{Y}$ symptom

$\mathrm{n} \quad=$ The number of samples observed

$\mathrm{X}=$ Score of $\mathrm{X}$ symptom

$\mathrm{Y} \quad=$ Score of $\mathrm{Y}$ symptom

With the test criteria if $r_{\text {count }}>r_{\text {table }}$ with $\alpha=0,05$ then the measuring instrument is declared valid, and vice versa, if $r_{\text {count }}<r_{\text {table }}$ then the measuring instrument is not valid.

\section{Reliability Test}

Reliability is the consistency of a series of measurements or a series of measuring instruments. Research is considered reliable when providing consistent results for the same measurements. It cannot be relied on if repeated measurements give different results. This study uses alpha formula to test reliability:

$$
\mathrm{r}_{11}=\left[\frac{n}{(n-1)}\right]\left[1-\frac{\sum \alpha_{t}^{2}}{\alpha_{t}^{2}}\right]
$$


Information:

$r_{11} \quad=$ Instrument Reliability

$\sum \alpha_{t}^{2} \quad=$ Score each item

$n \quad=$ The number of questions

$\alpha_{t}^{2} \quad=$ The number of variants

(Arikunto, 2008: 109)

The reliability test criteria with alpha formula is $r_{\text {count }}>r_{\text {table }}$ then the measuring instrument is declared valid, and vice versa, if rcount $<$ rtable then the measuring instrument is not reliable.

With testing criteria if the price rcount $>$ rtable with $\alpha=0,05$ so the measuring instrument is declared reliable, and vice versa, if $r_{\text {count }}<r_{\text {table }}$ then the measuring instrument is not reliable.

\section{Normality Test}

The normality test uses the Lilliefors test. Based on the sample to be tested the hypothesis, whether the sample is normally distributed or vice versa. It is using formula:

$\mathrm{L}_{\mathrm{o}}=\mathrm{F}\left(\mathrm{Z}_{\mathrm{i}}\right)-\mathrm{S}\left(\mathrm{Z}_{\mathrm{i}}\right)$

Information:

$\mathrm{L}_{\mathrm{o}} \quad=$ The highest absolute price

$\mathrm{F}\left(\mathrm{Z}_{\mathrm{i}}\right)=$ Standard number opportunity

$\mathrm{S}\left(\mathrm{Z}_{\mathrm{i}}\right)=$ Standard number proportion

(Sudjana,2005:466)

The test criteria are if $\mathrm{L}_{\text {count }}<\mathrm{L}_{\text {table }}$ with the significant alphabet 0.05 then the variable is normally distributed and vice versa. 
4. Homogeneity Test

Homogeneity test is using the $\mathrm{F}$ test formula

$$
\mathrm{F}=\frac{\text { The highest variances }}{\text { The lowest variances }}
$$

(Sugiyono,2011:276)

In this case the provision applies if $F_{\text {count }} \leq F_{\text {table, }}$, then the sample data will

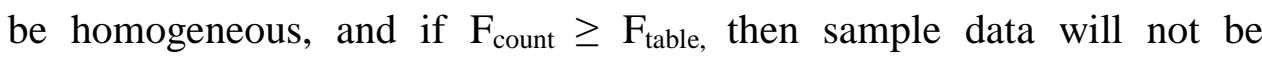
homogenous with significant level 0.05 and $d k\left(n_{1}-1 ; n_{2}-1\right)$.

\section{Two Independent Sample T-test tests}

There is a formula accorded to Sugiyono $(2014 ; 184)$ in testing hypothesis (T-test) this research is:

$$
\mathrm{t}=\frac{r \sqrt{n-2}}{\sqrt{1-r^{2}}}
$$

\section{Analysis of Variances in Two Way}

Two-way analysis is a research data analysis technique with a two-factor factorial design (Arikunto, 2006:424). This study uses two-way ANOVA to determine the level of significance of differences in two methods of learning Geography.

Data analysis techniques are carried out before data collection. This data analysis refers to the models of Miles and Huberman (1992):

\section{Reducing Data}

Reducing data is summarizing the main and important things. Thus, the reduced data will provide a clear picture and make it easier for researchers to collect and search for further data. 


\section{Data Presentation}

Data presentation is done in narrative form. Through the presentation of data, the data will be organized, arranged in relationship pattern so that it is easier to understand and plan the next steps based on what has been understood.

\section{Withdrawal Conclusion}

The final step in data analysis is drawing conclusion from the evaluation results and is the final disclosure of the results of the actions

\section{RESULTS AND DISCUSSION}

\section{RESULT}

At this stage, the author divides into 3 steps, there are the trial of research instruments, data collection research, and analysis of research data. The intended research test is to find out whether the questionnaire that has been made is feasible or not. Questionnaire that is feasible to use if it has validity and reliability that meets the requirements.

a. Validity and Reliability of Learning Outcomes and Learning Motivation Instruments

Validity and reliability test data on learning outcomes tests can be in the appendix. The results of trial analysis of the validity of the pretest and posttest questions concluded that out of the 20 questions tested, there were 4 questions that were declared invalid, it was 4, 9, 11 and 17. The four items were declared invalid because the value of $r$ calculate it is smaller than the table $\mathrm{R}$ value which is 0.32 . The 16 valid questions are used for research questions.

The results of the validity of the motivation questionnaire in the attachment. In the motivation questionnaire there are 10 questions, there are 2 invalid questions and 8 valid items. 
Learning outcomes questionnaire reliability test results are calculated by Cronbach alpha coefficient formula generated $\mathrm{r}$ value $=0.813$. A questionnaire is said to be reliable if the value of rcount > rtable. The results of calculation of reliability of the items indicate that the value of rcount $=0.813>0.32$ then the questionnaire on learning outcomes is reliable.

The results of student learning motivation questionnaire reliability test calculated by Cronbach alpha coefficient formula produced a value of $\mathrm{r}=$ 2.912744. A questionnaire is said to be reliable if the value of rcount > ttable. The results of the reliability calculation of items of motivation show that the value rcount $=2.912>0.32$ then the questionnaire on learning outcomes is reliable.

b. Analysis of the T test Two Sample Data

a) Average before using Audio Visual Media that is 62.3 in geography learning value. After using Audio Visual Media, it increases to 69.4. So, there is a descriptive increase.

b) The results of the variance are not mush different from the results of observation of the sample used, which is 32. With Degree of Freedom (df) $32-1$ is 31.

c) Based on these results it is knows t stat -2.543131064 . The value obtained is the same as the t-test material in pairs.

d) Besides, there is a descriptive in the form of Pearson correlation which is 0.283787649

e) The hypothesis used is "two-way hypothesis" so that it produces two tails, the result is t table which is 2.039513438 with $\mathrm{p}$ value 0.016194543 . it is because $\mathrm{p}$ value is smaller than alpha $5 \%$ or by looking at $\mathrm{t}$ count $<\mathrm{t}$ table, then the decision is accepted $\mathrm{H}_{\mathrm{o}}$ and $\mathrm{H}_{1}$ is rejected (no effect) 
f) Ho is accepted, so it is concluded that there is no significant difference between the results of geography learning before and after the application of streaming-based audiovisual video media.

c. Two Way ANOVA Test Analysis

Hypothesis Testing in the Two-Way ANOVA test:

a) Testing the hypothesis based on the output I gave in red, obtained the Sig value. As much as $0.452>0.05$, so the hypothesis states "Media does not significantly influence student learning outcomes"

b) Conducting hypothesis testing based on the output I gave blue, obtained by the value of Sig. As much as $0.14>0.05$, so the hypothesis states that "Motivation does not significantly influence the learning outcomes"

c) Testing the third hypothesis, based on the output given in green.

Hypothesis:

Ho: There is no relationship between the media towards student motivation and learning outcomes.

Ha: There is an interaction between audio-visual media and audiovisual and learning outcomes.

Decision-Making

If $\mathrm{F}$ count $<\mathrm{F}$ table or sig value $>0.05$, then Ho is accepted.

If $\mathrm{F}$ count $>\mathrm{F}$ table or sig value $<0.05$, then $\mathrm{Ho}$ is rejected, and $\mathrm{Ha}$ is accepted

The conclusion is obtained Sig value of $0.196>0.05$, so it can be inferred there is the relationship between audio visual media and student learning motivation. 


\section{DISCUSSION}

Based on the results of research on the use of Streaming Audio-Based Learning Media on Geography Subject Learning Outcomes on the subject of Hydrosphere Dynamics by Noting the Learning Motivation of class X IPS at Senior High School 1 Weru 2018 academic year can be described as follows:

1. Learning is a communication process that occurs in two directions, namely teaching carried out by teacher as an educator and learning conducted by students. Learning and teaching have the same purpose. Where the goal of a teacher is to increase student learning motivation and learning outcomes of each student, while the goals of students are how to study subject matter so that learning achievements increase or achieve good results. The use of instructional media can be varied so students do not feel bored in the learning process and can improve students learning outcomes.

Description above, it can be understood that the use of audio-visual media can affect learning outcomes in class. This is measured from the results of the posttest grade of final grade. It tuns out that the use of streaming based audio-visual video media does not have much influence on student learning outcomes. All of this is caused when students are given time to search learning resources on "youtube" they discuss to others. There is also a reason for not carrying a cellphone or laptop. General impression among students that geography is a memorization lesson. There is Lack of time for research, lack of facilities, and lack of infrastructure in school.

2. Motivation is basically a desire or encouragement that arises from within a person to do something. Desire arises because there is an encouragement from outside that can affect one's thinking. Learning 
motivation is the mental strength that drives the learning process. Each student has a different learning motivation. By the desire to learn that arises from within oneself will create a safe and conductive learning atmosphere where there is no compulsion in following the learning process in class.

From the description above, it is clear that motivation should be generated so that students can be enthusiastic in learning. If students' motivation in learning is high, the results will be maximal. There is no significant influence on the use of audio-visual media on learning motivation.

3. The results of the research that has been conducted show that there is a relationship between audio-visual media between learning outcomes and student motivation. Using learning media appropriately and varied will be able to overcome the passivity of students, causing excitement in learning, increasing students' understanding of geography subject matter and increasing learning achievement.

Likewise, with learning motivation, the existence of good motivation in learning will show good results. In other words, with diligent efforts and especially based on the motivation of students who learn it will produce good achievements.

The results expected by researcher is not in accordance with the hypothesis which states that student learning outcomes using streaming audio-based video audio media is better than not using streaming audio-visual video media. Student' high learning motivation by using streaming based audio-visual video media higher than not using streaming-based on audio visual video media, the results of this study are not accordance with the expected hypothesis because in its implementation students are less active in using streaming-based 
audio-visual media, they instead open sites that is different. Lack of research time, lack of learning facilities and infrastructure.

\section{CONCLUSIONS AND SUGGESTIONS}

\section{Conclusions}

Based on the formulation of the problem, the findings and discussion, the results of this study can be concluded that using the experimental method cannot improve students' understanding in comprehending the hydrosphere dynamics material in IPS X class of Weru 1 High School.

\section{Suggestions}

Based on the conclusions that have been discussed, some suggestions are given as follows:

1. To the school teacher, to use the experimental method as one alternative in enhancing students' understanding of concepts the subject matter, especially IPS material that emphasizes psychomotor aspects.

2. For teachers or other education practitioners who are interested in applying this form of learning, need to pay attention to the following:

a. Pay attention to and examine the activities in he stages of the experimental method so that the goals to be achieved in learning ca be obtained well.

b. Timing to be used in learning activities is considered carefully so that it can be in accordance with the planned time.

c. Teachers in applying the experimental method should emphasize the implementation of experiments conducted by students so that students can learn from their own experiences.

3. To the next researcher to develop research using experimental methods in increasing the competency of other students. 


\section{E. REFERENCE}

Arief S.Sadiman, dkk., Media Pendidikan : Pengetian, Pengembangan , dan Pemanfaatannya, Jakarta:PT Raja Grafindo Persada, 2007.

Arifin Zainal. Penelitian Pendidikan: Metode dan Paradigma Baru. Bandung: PT Remaja Rosdakarya, 2011.

Arikunto,suharsimi,Prosedur Penelitian:Suatu Pendekatan Praktik, Jakartya : PT Rineka Cipta.

Sugiyono, Metode Penelitian Pendidikan: Pendekatan Kuantitatif , Kualitatif, dan R\&D, (Bandung: Alfabeta,2013)

Sukmadinata.(2003).Landasan Psikologi Proses Pendidikan. Bandung: PT. Remaja Rosdakarya.

Zainal Arifin,Penelitian Pendidikan: Metode dan Paragdigma Baru, ( Bandung: PT Remaja Rosdakarya, 2011) 